\title{
Who Will Volunteer? Religiosity, Everyday Racism, and Social Participation Among African American Men
}

\author{
Jacqueline S. Mattis, ${ }^{1,4}$ William Pierce Beckham, ${ }^{2}$ Benjamin A. Saunders, ${ }^{3}$ \\ Jarvis E. Williams, ${ }^{2}$ D'Yal McAllister, ${ }^{2}$ Valerie Myers, ${ }^{2}$ Damon Knight, ${ }^{2}$ \\ Donald Rencher, ${ }^{2}$ and Charles Dixon ${ }^{2}$
}

\begin{abstract}
This study explores the relative importance of everyday racism, empathic concern, communalism, and religiosity as predictors of pro-social involvement (i.e., volunteerism and membership in political/social justice organizations) among a sample of African American men $(N=151)$. Church involvement emerged as a positive predictor of the likelihood that these men were involved in volunteer work as well as the number of hours that men dedicated to volunteer work. Communalism positively predicted the amount of time (in hours per year) that men were involved in volunteer work. Subjective religiosity and the stress of everyday racism were associated with a greater likelihood of being a member of a political-social justice organization. Implications of these findings are discussed.
\end{abstract}

KEY WORDS: volunteerism; African American; men; religiosity; racism; empathy.

African Americans have had a long tradition of involvement in social change and social justice movements. Through their voluntary participation in civil rights organizations, service guilds, and churchbased organizations, many African Americans have worked both to critique and radically alter unjust social and economic conditions (see Cohen \& Kapsis, 1978; Du Bois, 1961; Klobus-Edwards, Edwards, \& Klemmack, 1978; Lincoln \& Mamiya, 1990; Myrdal, 1944). Despite this tradition of pro-social involvement and the role of African American men in transforming America's social, economic, and political landscape, contemporary social scientific discourse continues to represent African American men principally as agents or victims of social crisis and social pathology (see Bowman \& Sanders, 1998, and Saint-Aubin,

\footnotetext{
${ }^{1}$ Department of Applied Psychology, Steinhardt School of Education, New York University, New York, New York.

${ }^{2}$ University of Michigan, Ann Arbor, Michigan.

${ }^{3}$ University of Illinois at Chicago, Chicago, Illinois.

${ }^{4}$ To whom correspondence should be addressed at Department of Applied Psychology, Steinhardt School of Education, New York University, 239 Greene Street, 4th Fl., New York, New York 10003; e-mail: jsm2015@nyu.edu.
}

2002, for a discussion; see also Bennett \& Fraser, 2000; Cubbin, Pickle, \& Fingerhut, 2000; Gary, 1981; Singh \& Siahpush, 2001). This skewed representation of African American men has obscured attention to the reality that many African American men actively participate in activities that promote community well-being. This exploratory study endeavors to shift the discourse about the lives of African American men by focusing on factors that are associated with these men's participation in pro-social activities. More specifically, this study endeavors to examine a model of African American male pro-social involvement that accounts for the roles of empathy, communal orientation, religiosity, and encounters with everyday racism in these outcomes.

\section{Theorizing African American Social Participation}

Within the social sciences there is a substantial body of empirical literature on volunteerism and social participation (see, e.g., Batson, 1994; Hayghe, 1991; Hoge, Zech, McNamara, \& Donahue, 1998; Musick, Wilson, \& Bynum, 2000; Regnerus, Smith, \& Sikkink, 1998). However, relatively little of that 
work has focused on volunteerism and social participation among ethnic minorities, and even fewer studies have been dedicated to studying these forms of pro-social involvement among African American men. The relative silence surrounding African American male pro-social participation exists in tandem with an urgent call by community activists for increased African American male involvement in social justice and social service activities. Some activists assert that African American men who are engaged in constructive pro-social service have a particularly important part to play in modeling appropriate male gender roles for young people who do not have immediate or sustained access to such models. Further, noting the disproportionate involvement of African American women in community life, some activists have argued that the involvement of men in activities that promote community welfare will help to more evenly distribute the burdens of social action. However, despite the urgency of the call for, and the presumed importance of male involvement in community life, social scientists know relatively little about the factors that are associated with African American male pro-social participation.

To date, efforts to theorize the involvement of African Americans in volunteer work and other forms of social participation have followed three general paths. First, some early theorists characterized African American volunteerism and social service involvement as compensatory in nature (Myrdal, 1944). Adherents to this approach asserted that African American men and women developed and involved themselves in pro-social organizational activities out of a need both to compensate for and to counteract the degradation that they experienced at the hands of racist mainstream culture (Myrdal, 1944). Certainly, history has demonstrated that African American men and women developed and participated in a range of service-oriented organizations that allowed them to exhibit a vast array of competencies. These organizations provided African Americans with opportunities to cultivate as well as to reinforce visions of themselves as agentic, empathic, and constructive members of society (Billingsley \& Caldwell, 1991; Du Bois, 1961; Giddings, 1988). However, the assertion that these organizations and, by extension, African American social and political participation, developed solely out of a need to compensate for the deleterious psychological effects of racism is both overly simplistic and empirically unsupported.

A second approach to pro-social involvement was advanced by theorists working at the height of the Civil Rights and Black Power movements. These theorists offered the "ethnic community approach" as an alternative explanation for African American social participation. The ethnic community thesis suggested that African American voluntarism and organizational involvement emerged out of the joint effects of shared oppression, a shared sense of destiny, and a concomitant racial solidarity (see Antunes \& Gaitz, 1975; Klobus-Edwards et al., 1978; Lane, 1959). Proponents of this ethnic community approach theorized that the pro-social involvement of African Americans resulted from a conviction among "ethnically identified" African Americans that voluntary social participation was a particularly effective way of achieving ethnic group survival.

Empirical work conducted by Olsen (1970) both challenged and advanced the ethnic community thesis by suggesting that shared experiences of oppression and a shared sense of ethnic identity may not be sufficient for promoting the participation of ethnic minorities in volunteer work and political life. Olsen suggested a third approach to African American prosociality. He argued that social and political participation also requires the existence of community or cultural norms that support involvement in such activities (Cohen \& Kapsis, 1978; Olsen, 1970). Few studies have directly examined the viability of Olsen's assertion that cultural norms are critical to promoting social and political participation. In this study, we examine the extent to which communalism - the cultural norm of interdependence and social obligationand religiosity are associated with African American men's social and political participation. Empirical work on the link between these constructs and prosocial involvement will be reviewed in the sections that follow.

Fundamental to the compensation, ethnic community, and normative approaches to African American social and political participation is the notion that real or perceived racism plays a key role in catalyzing social and political involvement. Indeed, anecdotal as well as archival data including the biographies and autobiographies of such prominent figures as Andrew Young and El Haaj Malik al Shabbaz (Malcolm X), suggest that some individuals who have been exposed to the pernicious effects of racism have been inspired by their experiences to engage in social action. However, psychology research has not explored the extent to which objective or perceived racism may be associated with African American men's pro-social involvement. This study endeavors to serve as a corrective to this gap. 


\section{Racism}

Importantly, a number of contemporary pundits have argued that race is declining in significance, and that racism has all but disappeared from the nation's social landscape (see Steele, 1990; Wilson, 1978). However, Feagin and Sikes (1994) cogently argue that racism has not disappeared, rather its face has transformed. Feagin et al. assert that "modern racism does not consist mainly of the isolated acts of scattered white bigots, but rather has been inescapable in the everyday worlds of African Americans" (p. 4). The term "everyday racism" distinguishes between periodic and isolated instances of overt racism and "the various types and expressions of racism experienced by ethnic groups in everyday contact with members of the more powerful (White) group" (Essed, 1990, p. 31). This pervasive form of racism includes subtle as well as blatant degradations that transpire in daily encounters between members of different ethnic groups.

Everyday racism is not new in social scientific lexicon. As with other forms of racism, a number of scholars have empirically examined its effects on the lives of African Americans (Clark, Anderson, Clark, \& Williams, 1999; Gee, 2002; Utsey, Ponterroto, Reynolds, \& Cancelli, 2000). These studies have sought to delineate the effects of racism on such psychosocial and physiological outcomes as life satisfaction, helplessness, depression, cardiovascular and immune dysfunction, and general health status (Armstead, Lawler, Gorden, Cross, \& Gibbons, 1989; Browman, 1996; Clark et al., 1999; Clark \& Harrell, 1982; Utsey et al., 2000; Williams, Yu, Jackson, \& Anderson, 1997). These studies suggest that encounters with racism carry dire health consequences. To date, it appears that few empirical studies have examined the extent to which encounters with everyday racism may be associated with resilient or agentic responses. However, there is reason to believe that encounters with racism may have paradoxical social effects. Indeed, racist encounters may serve as potent reminders of social inequity, and may catalyze, among some African Americans, a commitment to changing unjust or inequitable social conditions. Individuals who are thus inspired may use their experience with racism as a launching point for becoming involved in organizations that are aimed at transforming the lives of others, or in organizations focused on achieving social justice. This study examines the relationship between everyday racism and men's involvement in two forms of pro-social activity: volunteerism and membership in a political or social justice organization.

\section{Religion, Empathy, Communalism, and Social Participation}

Although racism has been identified as a potentially important predictor of pro-social involvement among African Americans, theorists and empirical researchers-including proponents of the community norms approach-also point to religion and communal orientation as crucial contributors to social participation. There is a body of work that asserts that in Black faith traditions there is an inextricable link between religiosity, social mission, and civic responsibility (Carson, 1990; Clayton, 1995; Cone, 1997; Lincoln \& Mamiya, 1990; Mattis, 2001; Mattis \& Jagers, 2001). Black churches and religious leaders have served as hubs for African American political mobilization (Billingsley, 1999; Harris, 1994; Reese \& Brown, 1995), leadership and educational development (Billingsley \& Caldwell, 1991), and economic development (Lincoln \& Mamiya, 1990; Williams, Griffith, Young, Collins, \& Dodson, 1999). Further, Black churches historically have played a central role in providing health care, psychological counseling, food, clothing and shelter, and other supports to community members who are in need (Billingsley, 1999; Caldwell, Chatters, Billingsley, \& Taylor, 1995; Carson, 1990; Chaves \& Higgins, 1992; Lincoln \& Mamiya, 1990; Neighbors, Musick, \& Williams, 1998; Williams et al., 1999). Through these kinds of activities churches have both reinforced the importance of the link between religion and social participation, and provided concrete opportunities for church members to become involved in benevolent service and prosocial activities (Arp \& Boeckelman, 1997; Billingsley \& Caldwell, 1991; Hodgkinson, Weitzman, \& The Gallup Organization, 1996; Hodgkinson, Weitzman, \& Kirsch, 1990; Mattis, 2001; Musick, et al., 2000; Regnerus et al., 1998; Smith, Fabricatore, \& Peyrot, 1999). As such, it is expected that church involvement will be associated with an increased likelihood of involvement in pro-social activities.

Participation in formal organizational religious life represents one path through which the religiositypro-sociality link may be forged. However, subjective religiosity is another potentially important correlate of pro-social involvement. Although there is some evidence that the strength of subjective religious beliefs is negatively related to volunteerism among Blacks 
(Musick et al., 2000), there is some evidence that subjective religiosity is an important predictor of social participation (Mattis et al., 2000). Individuals who are religious, and/or who indicate that religion is important to them, are more likely to engage in volunteer work (see Wilson \& Janoski, 1995). In sum, following from the findings of existing research, it is anticipated that men who are more involved in church life, and those who perceive themselves as more religious, are also particularly likely to be involved in volunteer work as well as in political-social justice organizations (Hodgkinson et al., 1990; Hoge et al., 1998; Wuthnow, 1991).

In keeping with Olsen's (1970) assertion that community/cultural values must be accounted for in studies of volunteerism, this study explores the link between communalism and pro-social participation. "Communalism" refers to a cultural orientation in which interdependence and social obligations are given precedence over personal needs (Boykin, Jagers, Ellison, \& Albury, 1997; Jagers \& Mock, 1995). Although scholars agree that African American culture generally is communally oriented (Boykin, 1986; Jagers, 1997; Jagers \& Mock, 1995; Nobles, 1991), empirical work on communalism among African Americans remains sparse. Empirical research with non-African American samples has found that communally oriented individuals tend to score higher on indices of generosity, cooperation, sharing, equality, and social justice than those who hold more individualistic orientations (Schwartz, 1990; Triandis, 1995; Triandis, Leung, Villareal, \& Clack, 1985; Triandis, McCusker, \& Hui, 1990). Mattis et al. (2000) found a link between communalism and the amount of time that men committed to volunteer work. In this study, it is anticipated that men who score higher on communalism will be more likely to be involved in volunteer work, will dedicate more time to this kind of work, and will be more likely to be involved in political/social justice organizations.

\section{Empathy}

Any effort to examine the link between religion and social involvement inevitably raises one question: To what extent is pro-social participation simply a consequence of individual level dispositions such as empathic concern? Certainly, findings regarding the link between empathy and altruism are quite robust (see, e.g., Eisenberg \& Miller, 1987; Unger \& Thumuluri, 1997). Further, there is ample empirical support for the notion that people engage in volunteer work because of their empathic concern for less fortunate others (Cialdini, Brown, \& Lewis, 1997; Litvak-Miller, McDougall, \& Romney, 1997). However, the extent to which empathy is associated with pro-social participation among African American men has not been examined in empirical research. This study seeks to rectify this gap in the empirical literature.

In summary, this study endeavors to advance psychology research on the lives of African American men by examining the extent to which encounters with everyday racism, subjective religiosity, church involvement, communalism, and trait empathy inform men's involvement in volunteer work, and in social justice organizations. It is anticipated that each of these indices will emerge as positive predictors of each index of pro-social participation. Given previous findings that suggest that age is a predictor of volunteerism (Goss, 1999), and given that age is often associated with greater reported religiosity (Taylor \& Chatters, 1991), we include age in each of the models of participation.

\section{METHOD}

The participants in this study are 151 African American men residing in metropolitan Georgia, Maryland, Michigan, New York, and Virginia. Consistent with the principles of community-based research outlined by Israel, Schulz, Parker, and Becker (1998), these men were recruited with the assistance of knowledgeable community residents. These knowledgeable residents recruited participants by means of fliers, electronic mail, public announcements, and/or wordof-mouth in a variety of settings in these metropolitan areas. Residents targeted sites that were frequented by African American men. Among these sites were community centers in Michigan and New York City, and businesses frequented by African American men (e.g., barbershops), the campus of a historically Black college in the Southeastern United States, the campus of a predominately White university in the midwest, and predominately African American churches. Initial data collection efforts resulted in a snowball effect-many of the participants volunteered to distribute surveys to other men. Surveys were collected within 3 weeks of the original date of distribution. During that 3-week period participants were reminded (e.g., public announcements) of the importance of returning the completed survey. Each participant received $\$ 5$ for completing and returning the 
survey. Community residents were not compensated for their participation.

\section{Participants}

Participants ranged in age from 17 to 79 years $(M=30.63, S D=16.12)$. One percent of participants have earned less than a HS diploma, $12 \%$ have earned a HS diploma or GED, 56\% have completed at least some college courses, $14 \%$ have earned a college degree, and $18 \%$ have earned a professional degree. Seventy percent of the respondents report that they are single (never married). Twenty-six percent are married, and $4 \%$ are divorced or widowed. The annual household incomes of these men ranged from "less than $\$ 9,999$ " to " $\$ 80,000$ or higher." However, their median combined household income range was $\$ 50,000-\$ 59,999$. According to U.S. census data $39 \%$ of African Americans have earned HS diplomas, 19\% have taken some college courses but have not earned a degree; $17 \%$ have earned college degrees, and 4\% have earned advanced degrees (Statistical Abstracts of the United States, 1998). Further, census data indicate that the median household income for African American families is $\$ 26,522$ (Statistical Abstracts of the United States, 1998). These data reinforce the point that the participants in this study have a higher level of educational attainment and higher combined household incomes than is representative of African Americans generally.

\section{Independent Measures}

The stress associated with everyday racism was measured using an 18-item Daily Life Experience of Racism Scale (DLER; Harrell, 1997). Respondents were asked to indicate how often, in the past year, they experienced each event because of their race. Sample items include "Being mistaken for someone else of your race"; "Others expecting your work to be inferior"; and "Being mistaken for someone who serves others (i.e., janitor, bellboy)." The frequency with which these events occurred was measured on a 6 -point Likert scale $(0=$ did not happen, $1=$ once, $2=$ a few times, $3=$ about once a month, $4=a$ few times $a$ month, $5=$ once a week or more). For each event on the DLER, respondents were also asked, "How much does it bother you?" $(1=$ doesn't bother me at all, $2=$ bothers me a little, $3=$ bothers me somewhat, $4=$ bothers me a lot, $5=$ bothers me extremely). For each participant, an overall everyday racism stress score was calculated by weighting the frequency with which each event occurred by the reported stress associated with that event, and then summing the scores for all 18 items of the measure. Everyday racism stress scores could range from 0 (no encounters with racism) to 450 .

Empathic Concern was measured with four items from the Empathy Scale (Davis, 1983). The items on this measure included "When I see someone being taken advantage of I feel kind of protective toward them." Items were scored on a 5-point Likert scale $(1=$ not at all like me to $5=$ very much like me $)$. The alpha coefficient for this measure was .64.

In keeping with the work of Levin, Taylor, and Chatters (1995) and Taylor, Mattis, and Chatters (1999), Subjective Religiosity (SR) was measured as a composite of three items: "How religious are you?" $(1=$ not at all religious to $5=$ very religious $)$; "How important is religion in your life today?"; and "How important is it for African Americans to take their children to church?" $(1=$ not at all important to $5=$ very important). An alpha reliability coefficient of .88 was calculated for the SR scale.

Early Religious Involvement (ERI) was measured as a composite of four items that focused on the level of early personal and parental organizational religious involvement, and the level of importance that respondents' families attached to religion. The items that comprised this index were "How often did you attend church as a child?"; "When you were growing up how often did your mother attend church?"; "When you were growing up how often did your father attend church?"; and "How important was religion to your family when you were growing up?" Each of these items was measured on a 5-point Likert scale $(1=$ never $/$ not at all to $5=$ very $)$. The Cronbach alpha coefficient for the ERS measure was .72.

Current Church Involvement (CI) was measured as a sum of participants' responses to four dichotomously scored questions: "Are you a member of a church or religious institution?"; "Are you a member of a church-based organization or club (choir etc.)?"; "Have you ever held a leadership role in the church (Sunday School teacher, deacon etc.)?"; "Do you presently hold a leadership position in the church?" Each "no" response was scored as 0 and each "yes" was scored as 1 . Consequently, scores on the $\mathrm{CI}$ index could range from 0 (no involvement) to 4 (high level of involvement).

Communalism was measured with the 31-item Communalism Scale (CS; Boykin et al., 1997; Jagers 
Table I. Intercorrelations of Independent and Dependent Variables $(N=151)$

\begin{tabular}{|c|c|c|c|c|c|c|}
\hline & 1. & 2. & 3. & 4. & 5. & 6. \\
\hline 1. Empathy & - & & & & & \\
\hline 2. Communalism & $.30^{* * *}$ & 一 & & & & \\
\hline 3. Subjective religiosity & $.22^{* *}$ & $.31^{* * *}$ & - & & & \\
\hline 4. Current church involvement & $.20^{*}$ & $.26^{* * *}$ & $.59^{* * *}$ & - & & \\
\hline 5. Early religious involvement & $.21^{* *}$ & $.33^{* * *}$ & $.37^{* * *}$ & $.29^{* * *}$ & 一 & \\
\hline 6. Stress due to everyday racism & $.17^{*}$ & .11 & -.03 & -.01 & .07 & \\
\hline 7. Log of volunteer & .14 & $.28^{* * *}$ & $-.24^{* *}$ & $.43^{* * *}$ & $.17^{*}$ & .05 \\
\hline
\end{tabular}

\& Mock, 1995). The CS assesses the extent to which individuals endorse values of social obligation and interdependence. Items on the CS are measured on a 6 -point Likert scale $(1=$ completely false to $6=$ completely true). Sample items from the CS include "I am constantly aware of my obligation to family and friends," "I place high value on social relations among people," and "I take care of my own needs before I consider the needs of others" (reverse scored). Jagers and Mock (1995) report alpha coefficients for this scale ranging from .83 to .87 . An alpha coefficient of .89 was generated for the present sample.

\section{Dependent Measures}

Volunteerism was measured using a single item: "Are you involved in any volunteer activities?" This item was scored dichotomously $(0=$ "no" and $1=$ "yes").

Hours Volunteered Each Year was scored with a single, open-ended item: How many hours per year do you spend doing volunteer work?"

Membership in political-social justice organizations was also measured with a single, dichotomously scored item: "Are you a member of a political organization (NAACP; Urban League etc.)?" $(0=$ "no" and $1=$ "yes").

\section{RESULTS}

Analyses revealed that the indices of empathy, subjective religiosity, and communalism had adequate internal consistency $(\alpha=.64, .88$, and .89 , respectively). The majority of the participants perceived themselves to be very empathic $(M=3.84, S D=$ $0.65)$, very subjectively religious $(M=4.04, S D=$ $0.98)$, and as more communal than not $(M=4.30$, $S D=0.60)$. The everyday racism stress scores ranged from 0 to $415(M=116.70, S D=80.81)$. On average, respondents reported experiencing racist events at least "a few times" in the past year $(M=2.08, S D=$ $0.95)$. Further, they reported that they were somewhat bothered by these events $(M=3.11, S D=1.08)$.

Zero-order correlational analyses were used to examine the bivariate relationship between the independent variables (see Table I). Empathic concern was significantly and positively related to communal$\operatorname{ism}(r=.30, p \leq .001)$, subjective religiosity $(r=.22$, $p \leq .01)$, current church involvement $(r=.20, p \leq$ $.05)$, and early religious involvement $(r=.21, p \leq$ $.01)$. Empathic concern also was positively and significantly related to the stress associated with everyday racism scores $(r=.17, p \leq .05)$. Communalism $(r=$ $.28, p \leq .001)$, subjective religiosity $(r=.24, p \leq .01)$, current church involvement ( $r=.43, p \leq .001)$, and early religious involvement $(r=.17, p \leq .05)$ were positively and significantly related to the number of hours volunteered each year.

Direct logistic regression analyses were performed in order to explore the effects of empathic concern, communalism, the stress associated with everyday racism, early religious involvement, subjective religiosity, and current church involvement on the likelihood of involvement in volunteer work (see Table II), and membership in a political and/or social justice organization (see Table IV). Each table reports regression coefficients, Wald statistics, odds ratios, and $95 \%$ confidence intervals for the odds ratios for each of the predictors. In the model predicting membership in a political or social justice organization, 21 individuals were removed from the analyses because of missing data on one or more variables. Analyses revealed no differences between those included in and those excluded from these models. To account for the potential impact of age on involvement in volunteer work, and membership in political and/or social justice organizations we segmented the sample into three age groups: 17 - to 21-year olds $(n=76, M=$ $20 ; S D=1.24)$, 22- to 40 -year olds $(n=40, M=26$; $S D=5.49)$, and 41- to 79-year olds ( $n=35, M=55$; 
Table II. Logistic Regression Analysis Predicting Volunteerism $(N=151)$

\begin{tabular}{|c|c|c|c|c|}
\hline Variables & $B$ & $S E$ & Wald test (z) & Odds ratio $(\mathrm{CI})$ \\
\hline Age $17-21^{a}$ & $0.42^{*}$ & 0.22 & 1.91 & $1.53(1.00-2.33)$ \\
\hline Age $22-40$ & $-0.42^{*}$ & 0.22 & -1.91 & $0.65(0.43-0.99)$ \\
\hline Empathic concern & 0.08 & 0.30 & 0.27 & $1.09(0.60-1.95)$ \\
\hline Communalism & -0.26 & 0.33 & -0.79 & $0.77(0.40-1.47)$ \\
\hline Everyday racism & 0.00 & 0.00 & 0.00 & $1.00(0.99-1.00)$ \\
\hline Subjective religiosity & 0.00 & 0.22 & 0.00 & $1.00(0.65-1.55)$ \\
\hline Early religious involvement & 0.22 & 0.22 & 1.00 & $1.25(0.81-1.93)$ \\
\hline Current church involvement & $0.47^{* *}$ & 0.17 & 2.76 & $1.60(1.16-2.20)$ \\
\hline Model $\chi^{2} / d f$ & \multicolumn{2}{|c|}{$18.23 / 8^{*}$} & & \\
\hline Pseudo $R^{2}$ & \multicolumn{2}{|c|}{.15} & & \\
\hline
\end{tabular}

${ }^{a} 41$ - to 79-year-old men serve as the reference group for these analyses.

${ }^{*} p \leq .05$. $^{* *} p \leq .01 .{ }^{* * *} p \leq .001$.

$S D=10.37)$. Two factors guided the creation of these groups. First, on a pragmatic level, we had to ensure that the groups were sufficiently large to allow for meaningful and stable comparisons. Second, we were interested in creating groups that were conceptually meaningful. Researchers have found a curvilinear relationship between age and volunteerism (Mattis et al., 2000; Wilson \& Musick, 1997). It appears that the level of volunteerism that is evident in adolescence and early adulthood declines as individuals become more attentive to family and career demands. Volunteerism increases again as individuals become older, as their professional lives stabilize, and as children leave home. Another decline is seen as health concerns begin to impact people's mobility and their ability to engage in sustained activities. Following these findings, we reasoned that college-aged men (17- to 21-year olds) might be especially involved in volunteer and social justice work. We anticipated that men in the 22- to 40-year range would be in a developmental period in which they would be particularly focused on career and family concerns. In sum, this middle group would be less involved in volunteer or social justice work. Finally, we anticipated that men in the older group would have established themselves in their careers, would (if they were parents) be more likely to have older children, and would be more likely to have the time to engage in pro-social activities. We further reasoned that these men would be more involved in volunteer work and social justice activities because they came of age during a time in American history when Civil Rights and social justice oncerns were central in the cultural landscape.

The logistic regression model for volunteerism was significant, $\left.\chi^{2}(8,151)=18.23, p \leq .05\right)$. However, only current church involvement reliably predicted of the odds that men were involved in volunteer work $(z=-2.76, p \leq .01)$. The probability of volun- teering increased by a multiplicative factor of 1.60 with each unit increase in church involvement (see Table II).

The regression model predicting the likelihood of membership in a political or social justice organization was also significant, $\left.\chi^{2}(8,130)=56.33, p \leq .000\right)$ indicating that, together, these variables effectively distinguished between men who are members of politically oriented organizations and those who are not (see Table III). The findings indicate that relative to men in the 41 and older age group, men who are 17to 21-year old, and those who are 22- to 40-year olds were significantly less likely to be members of political and social justice organizations $(z=5.41, p \leq .05$ and $z=12.53, p \leq .000$, respectively). The Wald criterion identified subjective religiosity $(z=3.59, p \leq .05)$ and the stress related to everyday $\operatorname{racism}(z=10.03$, $p \leq .01)$ as significant positive predictors of the likelihood of membership in political/social justice organizations. Each unit increase in men's levels of subjective religiosity was associated with an approximatly 2 fold increase of belonging to a political/social justice organization. With each unit increase in stress due to everyday racism there was a corresponding $1 \%$ increase in the likelihood of belonging to a political/social justice organization.

An ordinary least squares regression analysis was performed in order to explore the direct relationships between the independent variables and the number of hours volunteered each year (see Table IV). Thirtyone participants were excluded from the model predicting the number of hours volunteered each year because of missing data on one or more variables. Owing to the skewed dispersion of the number of hours volunteered each year, this variable was logarithmically transformed. As with the other regression models, all independent variables were entered into this regression equation in a single block. The regression model 
Table III. Logistic Regression Analysis Predicting Membership in Political or Social Justice Organizations $(N=138)$

\begin{tabular}{lcccl}
\hline \multicolumn{1}{c}{ Variables } & $B$ & $S E$ & Wald test $(z)$ & Odds ratio $(\mathrm{CI})$ \\
\hline Age 17-21 & -4.45 & 1.26 & $12.53^{* * *}$ & $0.01(0.001-0.14)$ \\
Age 21-40 & -1.30 & 0.56 & $-5.41^{*}$ & $0.27(0.09-0.82)$ \\
Empathic concern & -0.03 & 0.39 & 0.004 & $0.95(0.46-2.09)$ \\
Communalism & 0.30 & 0.45 & 0.45 & $1.35(0.56-3.29)$ \\
Everyday racism & $0.01^{* *}$ & 0.003 & 10.03 & $1.01(1.00-1.02)$ \\
Subjective religiosity & $0.76^{* *}$ & 0.40 & 3.59 & $2.13(0.97-4.68)$ \\
Early religious involvement & 0.31 & 0.32 & 0.95 & $1.36(0.73-2.53)$ \\
Current church involvement & 0.06 & 0.21 & 0.08 & $1.06(0.70-1.61)$ \\
Model $\chi^{2} / d f$ & $56.33 / 8^{* * *}$ & & \\
Pseudo $R^{2}$ & .48 & & \\
${ }^{*} p \leq .05 .^{* *} p \leq .01 .{ }^{* * *} p \leq .001$. \\
\end{tabular}

was significant, $F(8,131)=5.16, p<.000)$. Together the independent variables predicted $24 \%$ of the variance in the (log of the) number of hours that men volunteered each year (see Table IV). Analyses revealed that 21- to 40-year-old men dedicated significantly fewer hours to volunteer work than their younger or older counterparts $(\beta=-.26, p \leq .05)$. Communalism $(\beta=.19, p \leq .05)$ and current church involvement $(\beta=.38, p \leq .001)$ emerged as significant, positive predictors of the amount of time that men dedicated to volunteer work each year.

\section{DISCUSSION}

In his frequently cited text, The Souls of Black Folk, Du Bois (1961) asked a question that is at the heart of twentieth and twenty-first century mainstream discourse about African American men: "How does it feel to be a problem?" Contemporary psychology's disproportionate focus on African American men as nihilistic and socially disruptive suggests that scholars continue to see these men as "problems."

Table IV. Regression Analysis Predicting Number of Hours Volunteered per Year $(N=139)$

\begin{tabular}{lll}
\hline \multicolumn{1}{c}{ Variables } & \multicolumn{1}{c}{$\beta$} & \multicolumn{1}{c}{$S E$} \\
\hline Age 17-21 & -.15 & 0.48 \\
Age 21-40 & $-.26^{*}$ & 0.48 \\
Empathic concern & -.02 & 0.28 \\
Communalism & $.19^{*}$ & 0.31 \\
Everyday racism & .08 & 0.00 \\
Subjective religiosity & -.09 & 0.22 \\
Early religious involvement & -.01 & 0.22 \\
Current church involvement & $.38^{* * *}$ & 0.16 \\
$R^{2}$ & \multicolumn{2}{c}{$.24^{* * *}$} \\
Adjusted $R^{2}$ & \multicolumn{2}{c}{$.19^{* * *}$} \\
${ }^{*} p \leq .05 .{ }^{* *} p \leq .01 .{ }^{* * *} p \leq .001$.
\end{tabular}

The relative lack of focus on the activist traditions of African American men reinforces a vision of African American men as people who are acted upon, or who act in ways that are consistently antisocial. If psychology is to fulfill its mission of accurately examining the lives of individuals and communities, then studies of the lives of African American men must make room for theorizing and empirically examining male prosocial agency. In the effort to fill the void this study endeavored to address two crucial questions: What are the factors that are associated with pro-social involvement among African American men? To what extent do these data support or challenge the compensation, ethnic community, and social norms approaches to involvement? Our findings indicate that for the men in this sample the factors that are associated with general volunteerism are distinct from those that are associated with membership or involvement in social justice organizations.

Age did not have direct bearing on the likelihood that men would be involved in volunteer work. However, age was associated with the amount of time that men dedicated to volunteer work and with the likelihood that men would be involved in political/social justice organizations. Men in the 21- to 40-year-old group dedicated significantly less time to volunteer activities than did their older counterparts. Men, aged 17-40, were also less likely to report membership in political/social justice organizations. It may be the case that the younger men may have family and or professional obligations that preclude membership in social justice organizations. However, two important points bear consideration. First, men in this study were asked about their membership in social justice organizations rather than about their involvement in social justice activities. It may be the case that younger men are embedded in organizations (e.g., fraternities) that provide opportunities for activism even though 
these organizations are not, by definition, social justice organizations. It may also be the case that some men involve themselves in social justice activities on an individual basis rather than under the rubric of a specific organization.

A common thread running through each theory is the notion that encounters with racism may serve as catalysts for (or may significantly be associated with) involvement. The findings lend partial support to that thesis. Importantly, the amount of distress that men report experiencing as a result of everyday racism emerged as a significant predictor of the likelihood of these men's involvement in political-social justice organizations. Men who reported a greater level of stress due to everyday racism were more likely to be involved in political/social justice organizations. However, the stress associated with everyday racism had no direct effect on either the likelihood that men were involved in volunteer activities or on the amount of time that men dedicated to volunteer work. These data are cross-sectional, as such the usual cautions regarding assumptions of causality apply here. It is possible that stressful encounters with everyday racism inspire men to become involved in social change and social justice activities. However, we must consider that men who are more involved in political and social justice organizations may find themselves in contexts where they are especially likely to experience everyday racism. Further, we must remain aware that some men who are involved in social justice organizations may be particularly likely to perceive or interpret unjust arrangements through the lens of racism. Longitudinal research on the relationship between exposure to racism and various forms of pro-social civic engagement will allow us to more clearly examine concerns about the directionality of these relationships.

The results of this study reveal a complex story regarding the impact of religiosity on social participation. Consistent with the findings of Musick et al. (2000) and Mattis et al. (2001), current church involvement emerged as a positive predictor of the likelihood that men would be involved in volunteer work, as well as of the amount of time that men gave to this kind of work. However, current church involvement had no direct effect on the likelihood that men were involved in political/social justice organizations. In fact, it was subjective religiosity, rather than institutional religious involvement that predicted membership in political/social justice organizations. These findings suggest that there may be different pathways between religiosity and various forms of social participation. Institutional religious participation may provide men with concrete opportunities to become involved in general forms of volunteer work. Men who are more involved in church life may have a higher probability of being exposed to (or invited to participate in) general volunteer activities. However, for men, participation in organized religion may be less directly relevant to becoming involved in political/social justice organizations. That is, secular contexts may provide men with ample opportunities to become exposed to or involved in political/social justice organizations.

The pattern of findings regarding subjective religiosity suggests that there may be a crucial link between the importance that men place on their constructions of themselves as religious beings (i.e., subjective religiosity) and the importance that they place on political-social justice work. Archival data suggest that for many African Americans the endorsement of liberationist and/or nationalist political ideals and the willingness to fight for social justice are crucial indices of personal religious authenticity (see Cone, 1997; Mattis, 2001). From this perspective, for African American men, general volunteerism, although important, may be a less viable index of religious authenticity than social justice or political involvement. Organizations may also benefit both by directly appealing to men's subjective sense of themselves as religious people, and by helping men to see the link between volunteer work and their identities as religious people. This suggests that organizations that are interested in recruiting African American male volunteers may be well served by highlighting the sociopolitical significance of volunteer work.

Following from Olsen's (1970) cultural norms thesis the study hypothesized that men who more strongly endorsed communal values (i.e., cultural values of social obligation and interdependence) would be more likely to be involved in volunteer work and in political-social justice organizations. Our findings lend partial support to Olsen's community norms thesis. Contrary to the social norms thesis, this study found no significant relationship between communalism and the likelihood of being involved in either volunteer work or in a political/social justice organization. However, when other variables were controlled, communalism did emerge as a significant, positive predictor of the amount of time that men dedicated to volunteer work each year. These findings suggest that communalism may be particularly important as a predictor of men's levels of commitment to pro-social activities rather than a predictor of the likelihood of involvement in such activities. 
Contrary to Unger and Thumuluri's (1997) assertion regarding the link between empathy and prosociality, for this sample of African American men empathy did not emerge as a significant independent predictor of any of the three indices of pro-social participation. This finding suggests that for African American men in this sample, empathic concern was not sufficient to ensure pro-social action. It is important to acknowledge that the relatively high mean scores (e.g., low variability) on the empathy index and the relatively low reliability coefficient of this measure may account for the nonsignificant relationships between empathy and the outcomes variables. We were limited in this study by the availability of four, face valid empathy items. Future studies that employ alternative measures of empathy will help to clarify these findings.

The limitations of this study must be acknowledged. First, these findings are based on data gathered from a relatively small, well-educated, and materially secure sample of African American men. It is important to underscore that this topic is deserving of ongoing research involving larger and more demographically heterogeneous samples of African American men. Second, as with all studies that rely on selfreport data, and as is the case in studies that assess constructs that are likely to evoke socially desirable responses, the findings of this study must be viewed with caution. Finally, the use of snowball sampling procedures, although successful in engaging participants, does limit our ability to generalize these findings beyond this sample.

Despite these limitations, however, these findings have important implications. Taken together they point to the need for the inclusion of relevant cultural level as well as social contextual factors in studies of pro-social involvement. The findings also reinforce archival data and theoretical frameworks that suggest that racism is implicated in men's involvement in activities that promote social welfare. Further, they suggest that although African American men are often described as irreligious, religion (both institutional and subjective) are important in the lives of these men. More specifically, organizational as well as subjective religiosity appears to play an important role in the pro-social development of African American men.

The study highlights the importance of expanding the discourse around the lives of African American men to include African American male religiosity and pro-social outcomes. Further, the study highlights the importance of paying attention to the impact of such contextually meaningful factors as everyday racism in studies of the life experiences of African American men. The inclusion of such factors will, no doubt, be crucial in future efforts to more accurately model the factors that lead African American men (and women) to become involved in activities that promote the welfare of proximal as well as distal others.

The findings of this study must be appreciated against the backdrop of Musick et al.'s (2000) hallmark study of volunteerism. Musick and colleagues found that Blacks, regardless of education or income, are less likely than their White counterparts to be asked to volunteer. Importantly, those who are asked to volunteer tend to dedicate more time to volunteer work than do those individuals who seek out volunteer experiences on their own. Taken together with this work, Musick's findings suggest that although church participation may increase the likelihood that men will volunteer, the odds of African American male volunteerism may be substantially increased if deliberate efforts are made to invite these men, including church going men, to participate in volunteer work.

\section{ACKNOWLEDGMENTS}

This research was made possible through the generous support of a grant to the first author from the Positive Psychology Young Scholars Grants Program (PPYS) and a grant from the University of Michigan's Institute for Research on Women and Gender (IRWG). "This research was funded through the Templeton Foundation's Positive Psychology Young Scholar's Award which was granted to the first author."

\section{REFERENCES}

Antunes, G., \& Gaitz, C. (1975). Ethnicity and participation: A study of Mexican-Americans, Blacks and Whites. American Journal of Sociology, 80, 1192-1311.

Armstead, C., Lawler, K., Gorden, G., Cross, J., \& Gibbons, J. (1989). Relationship of racial stressors to blood pressure responses and anger expression in Black college students. Health Psychology, 8, 541-556.

Arp, W., III, \& Boeckelman, K. (1997). Religiosity: A source of Black environmentalism and empowerment? Journal of Black Studies, 28 (2), 255-267.

Batson, C. D. (1994). Why act for the public good? Four answers. Personality and Social Psychology Bulletin, 20, 603-610.

Bennett, M., Jr., \& Fraser, M. (2000). Urban violence among African American males: Integrating family, neighborhood, and peer perspectives. Journal of Sociology and Social Welfare, 27, 93-117.

Billingsley, A. (1999). Mighty like a river: The Black church and social reform. New York: Oxford University Press. 
Billingsley, A., \& Caldwell, C. (1991). The church, the family and the school in the African American community. Journal of Negro Education, 60, 427-440.

Bowman, P., \& Sanders, R. (1998). Unmarried African American fathers: A comparative life span analysis. Journal of Comparative Family Studies, 29, 39-56.

Boykin, A. (1986). The triple-quandry and the schooling of AfroAmerican children. In U. Neisser (Ed.), The school achievement of minority children. Hillsdale, NJ: LEA.

Boykin, A., Jagers, R., Ellison, C., \& Albury, A. (1997). Communalism: Conceptualization and measurement of an Afrocultural Social Orientation. Journal of Black Studies, 27, 409-418.

Browman, C. (1996). The health consequences of racial discrimination: A study of African Americans. Ethnicity and Disease, $6,148-153$.

Caldwell, C., Chatters, L., Billingsley, A., \& Taylor, R. (1995). Church-based support programs for elderly Black adults: Congregational and clergy characteristics. In M. Kimble, S. McFadden, J. Ellor, \& J. Seeber (Eds.), Aging, spirituality, and religion: A handbook (pp.306-324). Minneapolis: Fortress Press.

Carson, E. (1990). Patterns of giving in Black churches. In R. Wuthnow, \& V. Hodgkinson and Associates (Eds.), Faith and philanthropy in America: Exploring the role of religion in America's voluntary sector (pp. 232-252). San Francisco: Jossey-Bass.

Chaves, M., \& Higgins, L. (1992). Comparing the community involvement of Black and White congregations. Journal for the Scientific Study of Religion, 31, 425-440.

Cialdini, R. B., Brown, S. L., Lewis, B. P., Luce, C., \& Neuberg, S. L. (1997). Reinterpreting the empathy-altruism relationship: When one into one equals oneness. Journal of Personality and Social Psychology, 73, 481-494.

Clark, R., Anderson, N., Clark, V., \& Williams, D. (1999). Racism as a stressor for African Americans: A biopsychosocial model. American Psychologist, 54, 805-816.

Clark, V., \& Harrell, J. (1982). The relationship among Type A behavior, styles used in coping with racism, and blood pressure. Journal of Black Psychology, 8, 89-99.

Clayton, O. (1995). The churches and social change: Accommodation, moderation, or protest. Daedalus, 124, 101-117.

Cohen, S., \& Kapsis, R. (1978). Participation of Blacks, Puerto Ricans, and Whites in voluntary associations: A test of current theories. Social Forces, 56(4), 1053-1071.

Cone, J. (1997). God of the oppressed. New York: Orbis Books.

Cubbin, C., Pickle, L., \& Fingerhut, L. (2000). Social context and geographic patterns of homicide among US Black and White males. American Journal of Public Health, 90(4), 579587.

Davis, M. (1983). Measuring individual-differences in empathy: Evidence for a multidimensional approach. Journal of Personality and Social Psychology, 44, 113-126.

Du Bois, W. (1961). The souls of Black folk. Greenwich, CT: Fawcett Press.

Eisenberg, N., \& Miller, P. (1987). Empathy, sympathy and altruism. In N. Eisenberg \& J. Strayer (Eds.), Empathy and its development. Cambridge: Cambridge University Press.

Essed, P. (1990). Everyday racism. Alameda, CA: Hunter House.

Feagin, J., \& Sikes, M. (1994). Living with racism: The Black middleclass experience. Boston: Beacon Press.

Gary, L. (1981). Black men. Beverly Hills, CA: Sage.

Gee, G. (2002). A multilevel analysis of the relationship between institutional and individual racial discrimination and health status. American Journal of Public Health, 92, 615623.

Gibbs, J. (1988). Young Black males in America: Endangered, embittered and embattled. In J. Gibbs (Ed.), Young, Black and male in American: An endangered species. Dover, MA: Auburn House.
Giddings, P. (1988). When and where I enter: The impact of Black women on race and sex in America. New York: Bantam Books.

Goss, K. (1999). Volunteering and the long civic generation. Nonprofit and Voluntary Sector Quarterly, 28, 378-415.

Harrell, S. (1997). The Racism and Life Experience Scales (RaLES). Unpublished manuscript, California School of Professional Psychology, Los Angeles.

Harris, F. (1994). Something within: Religion as a mobilizer of African American political activism. The Journal of Politics, 56(1), 42-68.

Hayghe, H. (1991). Volunteers in the U.S.: Who donates their time? Monthly Labor Review, 114, 16-24.

Hodgkinson, V., Weitzman, M., \& Kirsch, A. (1990). From commitment to action: How religious involvement affects giving and volunteering. In R. Wuthnow \& V. Hodgkinson and Associates (Eds.), Faith and philanthropy in America: Exploring the role of religion in America's voluntary sector (pp. 93-114). San Francisco: Jossey-Bass.

Hodgkinson, V., Weitzman, M., \& The Gallup Organization (1996). Giving and volunteering in the United States: 1996 Edition. Washington, DC: Independent Sector.

Hoge, D., Zech, C., McNamara, P., \& Donahue, M. (1998). The value of volunteers as resources for congregations. Journal for the Scientific Study of Religion, 37(3), 470-480.

Israel, B., Schulz, A., Parker, E., Becker, A. (1998). Review of community-based research: Assessing partnership approaches to improve public health. Annual Review of Public Health, 19, 173-202.

Jagers, R., \& Mock, L. (1995). The Communalism Scale and collectivist-individualistic tendencies: Some preliminary findings. Journal of Black Psychology, 21(2), 153-167.

Klobus-Edwards, P., Edwards, J., \& Klemmack, D. (1978). Differences in social participation: Blacks and Whites. Social Forces, 56(4), 1035-1052.

Lane, R. (1959). Political life: Why and how people get involved in politics. New York: Free Press.

Levin, J., Taylor, R., \& Chatters, L. (1995). A multidimensional measure of religious involvement for African Americans. The Sociological Quarterly, 36(1), 157-173.

Lincoln, C., \& Mamiya, L. (1990). The Black church in the African American experience. Durham, NC: Duke University Press.

Litvak-Miller, W., McDougall, D., \& Romney, D. (1997). The structure of empathy during middle childhood and its relationship to prosocial behavior. Genetic, Social, and General Psychology Monographs, 123(3), 303-324.

Mattis, J. (2001). Religiosity and African American political life. Political Psychology: Special Issue: Psychology as Politics, 22(2), 263-278.

Mattis, J., Jagers, R., Hatcher, C., Lawhon, G., Murphy, E., \& Murray, Y. (2000). Religiosity, communalism and volunteerism among African American men: An exploratory analysis. Journal of Community Psychology, 28(4), 391-406.

Mattis, J. S., \& Jagers, R. (2001). A relational framework for the study of religiosity and spirituality in the lives of African Americans. Journal of Community Psychology: Special Issue on Spirituality: Vol. 2, 29(5), 519-539.

Musick, M., Wilson, J., \& Bynum, W. (2000). Race and formal volunteering: The differential effects of class and religion. Social Forces, 78, 1539-1571.

Myrdal, G. (1944). An American dilemma: The Negro problem and modern democracy. New York: Harper \& Brothers.

Neighbors, H., Musick, M., \& Williams, D. (1998). The African American minister as a source of help for serious personal crises: Bridge or barrier to mental health care. Health Education and Behavior, 25, 759-777.

Nobles, W. (1991). Extended self: Rethinking the so-called Negro self-concept. In R. Jones (Ed.), Black psychology (pp. 295304). Berkeley, CA: Cobb \& Henry. 
Olsen, M. (1970). Social and political participation of Blacks. American Sociological Review, 35, 682-697.

Reese, L., \& Brown, R. (1995). The effects of religious messages on racial identity and system blame among African Americans. The Journal of Politics, 57(1), 24-43.

Regnerus, M., Smith, C., \& Sikkink, D. (1998). Who gives to the poor? The influence of religious tradition and political location on the personal generosity of Americans toward the poor. Journal for the Scientific Study of Religion, 37, 481493.

Saint-Aubin, A. (2002). A grammar of Black masculinity: A body of science. Journal of Men's Studies, 10, 247-270.

Schwartz, S. (1990). Individualism-collectivism: Critique and proposed refinements. Journal of Cross-Cultural Psychology, 21, 139-157.

Singh, G., \& Siahpush, M. (2001). All cause-specific mortality of immigrants and native born in the United States. American Journal of Public Health, 91, 392-399.

Smith, H., Fabricatore, A., \& Peyrot, M. (1999). Religiosity and altruism among African American males: The Catholic experience. Journal of Black Studies, 29(4), 579597.

Statistical Abstracts of the United States. (1998). US Bureau of the Census, Washington, DC.

Steele, S. (1990). The content of our character. New York: St. Martin's Press.

Taylor, R., \& Chatters, L. (1991). Religious life of Black Americans. In J. S. Jackson (Ed.), Life in Black America (pp. 105-123). Newbury Park, CA: Sage Publications.

Taylor, R., Mattis, J., \& Chatters, L. (1999). Subjective religiosity: Findings from five national samples. Journal of Black Psychology, 25(4), 524-543.
Triandis, H. (1995). Individualism and collectivism. Boulder, CO: Westview Press.

Triandis, H., Leung, K., Villareal, M., \& Clack, F. (1985). Allocentric versus idiocentric tendencies: Convergent and discriminant validation. Journal of Research in Personality, 19, 395-415.

Triandis, H., McCusker, C., \& Hui, C. (1990). Multi-method probes of individualism and collectivism. Journal of Personality and Social Psychology, 59, 1006-1020.

Unger, L., \& Thumuluri, L. (1997). Trait empathy and continuous helping: The case of voluntarism. Journal of Social Behavior and Personality, 12(3), 785-800.

Utsey, S., Ponterroto, J., Reynolds, A., \& Cancelli, A. (2000). Racial discrimination, coping, life satisfaction, and selfesteem among African Americans. Journal of Counseling and Development, $78,72-80$

Williams, D., Griffith, E., Young, J., Collins, C., \& Dodson, J. (1999). Structure and provision of services in Black churches in New Haven, Connecticut. Cultural Diversity and Ethnic Minority Psychology, 5(2), 118-133.

Williams, D., Yu, Y., Jackson, J., \& Anderson, N. (1997). Racial differences in physical and mental health: Socioeconomic status, stress and discrimination. Journal of Health Psychology, $2,335-351$.

Wilson, J., \& Janoski, T. (1995). The contribution of religion to volunteer work. Sociology of Religion, 56(2), 137-152.

Wilson, J., \& Musick, M. (1997). Who cares? Toward and integrated theory of volunteer work. American Sociological Review, 62, 694-713.

Wilson, W. (1978). The declining significance of race. Chicago: University of Chicago.

Wuthnow, R. (1991). Acts of compassion: Caring for others and helping ourselves. Princeton, NJ: Princeton University Press. 